\title{
On Interpretation and Comprehension \\ in Translation: an Overview of Russian
}

\section{and Chinese Scholars}

\author{
Chen Shaojun ${ }^{\mathrm{a}}$ \\ and Yaroslav V. Sokolovsky ${ }^{\text {b* }}$ \\ ${ }^{a}$ Shanghai International Studies University \\ Junior Faculty Member \\ 550 Dalian Road (W.), Shanghai, China \\ ${ }^{b}$ Siberian Federal University \\ 79 Svobodny, Krasnoyarsk, 660041, Russia
}

Received 14.09.2016, received in revised form 05.10.2016, accepted 10.01.2017

Despite the apparent simplicity of the notion of interpretation to date there is no generally accepted point of view on this concept in linguistics in general. This article briefly describes the concept of interpretation and its degree of representation in the epistemological concepts of Chinese and Russian scholars. The author makes an attempt to give a brief overview of some existing concepts in the framework of this perspective, taking into account the translation specifics.

Keywords: Interpretation, translation, interpreting, problem of comprehension, problem of meaning, Chinese.

DOI: 10.17516/1997-1370-0067.

Research area: philology.

(C) Siberian Federal University. All rights reserved

* Corresponding author E-mail address: 13761243853@126.com; sokol_rus@hotmail.com 


\section{General Provisions}

Interpretation i.e. the act of comprehension, "unpacking" the sense of an utterance is an inseparable part of translation and interpretation. Broadly speaking, it is an integral element of a person's ability to communicate verbally, because communication always implies the idea of encoding and decoding of a signal. When we interpret or translate we deal with meanings (conventional, i.e. more or less generally accepted meanings of linguistic units), which he (or she) turns into a personal sense.

Before listing some Chinese and Russian ideas on the discussed phenomenon we would like to give a brief general outline of the gnoseological status of the interpretation (comprehension). First of all, quite often interpretation is regarded as a fundamental method of work with texts when texts are viewed as a special kind of iconic structures. The text is open to the plurality of meanings that exist in the social communication system. It appears in the unity of explicit and implicit non-verbalized values, literal and secondary, hidden meanings. Understanding is an art of comprehension of the meaning of signs transmitted from one mind to another, while interpretation, respectively, is believed to be an art of comprehension of recorded (written) signs and texts (Mikeshina, 2005, 100).

Secondly, it is noteworthy that scholars single out several types of interpretation: historical, psychological, grammatical, etc. (ibid), i.e. every time the interpreter is placed on a new position in relation to the interpreted "object", which speaks in favor of the hypothesis of A. Zalevskaya who states that the brain operates according to the principle of the hologram (Zalevskaya, 1999). For example, the psychological interpretation "opens the person's outlook, informing about his (her) intentions and feelings", whereas historical interpretation "puts the text in a framework of its relationship to the circumstances of its creation" (Mikeshina, 2005, 101).

We assume that interpretation as a phase of translation can be viewed in, at least, two perspectives: as a process of understanding and comprehension something in terms of psycholinguistics and as a process of understanding in terms of semiotics. The speaker has a certain thought in mind and intends to make the hearer recognize what he or she has just had in mind. The speaker chooses his or her words in the expectation that on the basis of the words spoken and the circumstances of the utterance, the hearer will be able to infer that the speaker has that thought (Gauker, 2003, 3).

In the following two sub-parts of our paper we are discussing general tendencies of the scientific approach to the concept of interpretation within the framework of interpreting and translation studies in Russia and China.

\section{Chinese Scholars on Interpretation in Translation}

Speaking about interpretation, Chinese scholars in relation to this area of studies apply certain limitations. These limitations are reflected not only in the relatively small number of theories, which relate to the "process of interpretation", but also are reflected in the lack of necessary attention to the "comprehension stage of translation or interpreting". However, for other scholars the investigation of "interpretation process" can be split into "translation" and "interpretation".

At present, Chinese scholars pay little attention to the theories explaining the process of interpretation. At the beginning of this century we experienced a wave of high scientific interest in this area for the first time since the studies of translation process in 1980's appeared in China. However, in many other areas adjacent to translation studies, which deal with "the process of interpretation", scholars simply use the theory of hermeneutics, 
or the overall acceptance, or criticism denied, so in the theoretical discourse related to this area one can hardly notice any concept which is of Chinese origin and which can be singled out as a cornerstone of "Chinese theory".

For example, although the book by Wang Yanhua (王彦华) «The Change of Translation Criteria in Terms of Hermeneutics" lists many Chinese scholars in this field - one of the earliest applications of hermeneutics in translation studies belongs to the scholar Yang Wuneng (杨 武能): as early as 1987 he proposed «the Cycle of Interpretation, Reception and Creation"; Similarly Zhang Derang (张德让) following the three principles of Gadamer decided to reexamine the historical misunderstanding in translation, cultural filtering, and re-translation phenomenon; then Zhu Jianping (朱健平) worked on his approaches from the perspective of philosophical hermeneutics explaining the concept of translation, putting forward the idea of "translation and interpretation", yet all of those works could not get rid of all philosophical and theoretical foundation of Western scholars and Western hermeneutics, especially ideas of Schleiermacher as the author of "the central theory", and Gadamer's three principles as a part of the research focus. So there was a fundamental lack of originality in explaining the process, as well as in thorough understanding of the theory.

In contrast, Xie Tianzhen (谢天振) in the paper "On the Original Sense of the Author and the Original Meaning of the Text. Hermeneutics and Translation Studies", explains the idea of the intentional (original) meaning and sense as a basis for the dialectical perspective on the relationship between interpretation and translation. In this way the studies of interpretation in China came to a multitude of new ideas. However, after this work Chinese scholars on the "interpretation process" did not put forward other innovative concepts or views.
Similarly, in terms of the sequence of interpretation Chinese scholars tend to put "interpretation before translation" and use it as a background and a basis to discuss other issues. Among them, Yuan Honggeng's position (袁洪庚) is slightly different from others. In analyzing the relationshipbetweenhermeneuticsandtranslation, in his view, interpretation is an important part throughout the whole translation process. According to Yuan Honggeng interpretation does not necessarily entail translation, but translation is inseparable from interpretation. Interpretation of Yuan Honggeng blurs the boundaries between interpretation and translation and the order in which they are supposed to follow one after the other; in other words, in terms of translation and interpretation there is no such thing as "before and after". Although he believes that there is no special significance in the discussion of the stages in which these two occur, but he also sticks to the idea of Chinese scholars about the status of interpretation process, stating that "although those two are closely intertwined, yet there is no relationship of absolute belonging between them".

In recent years, with the development of the cognitive science, technology development and biological research for translation industry, the investigation of the interpretation process may usher in a new wave of findings in this area. In this regard, China's major colleges and universities are also actively involved in the related work at home and abroad in order to be able to contribute to changes in the paradigm of the cognitive science and provide a clearer and more structured understanding of what interpretation process is.

\section{Russian Scholars on Interpretation in Translation}

Speaking about Russian academic views on the notion of interpretation one cannot ignore the contribution of the Russian school of 
psycholinguistics. The representatives of this school believe that meaning is a certain reflection of reality, embodied in a language sign. According to A.N. Leontiev, meaning is what can be opened in an object or phenomenon objectively, in a system of objective relations, its interaction with other objects. Meaning is embodied in a sign, hence it acquires stability and is included in the content of the social consciousness (Leontiev, 1972 , p. 288-289), and meanings "represent a reformed and rolled in the language matter ideal form of existence of the objective world with its properties, connections and relationships, discovered by social practice" (Leontiev, 1975, p. 140-141).

V.Z. Demyankov writes that interpretation is an attempt to create the meaning in accordance with certain objectives, for which certain strategies are used. Only under this type of circumstances a language utterance becomes a meaning that forms a sense and its reference and therefore adjusts, narrows or even radically changes the already formed inner world of the interpreter. The meaning of the speech harmonizes the utterance with the preceding context. The meaning of the expression can be called a value of speech, actualized in the immediate situation of interpretation. Results are perceived externally (such as, for example, a response and text retelling) or one can only guess about them. However, in order to reach a success the interpreter is supposed not just to understand and pass on to others his (her) understanding of a work: a piece of music, literature, etc. Thus, we can single out: 1) linguistic meaning of basic, irreducible units of mental lexicon, 2) speech values, which are "calculated" through the process of interpretation.

Today, due to the studies of the $20^{\text {th }}$ century (especially in different varieties of hermeneutics and cognitive science), we have a certain understanding in terms of how the procedures of "calculation" in interpretation look like. However, as for the "storage room" from which these "basic" values are taken for the interpretation, it is still not entirely clear yet. It is also unclear how these units are shaped in the form of a language, in music, in visual signs (for painting), etc. (Demyankov, 2001, 67-68).

Many Russian scholars of the $20^{\text {th }}$ century consider interpretation to be an integral part of the translation (interpreting) process. For example, V.N. Komissarov (Komissarov 1982) devoted one of his works to that phenomenon. Common knowledge is that the interpreter (translator) is not a full member of a multi-language communicative act, because he (she) does not have the right to express his (her) own point of view and must fully focus on the original. In this regard, V.N. Komissarov writes that any translation process, however, contains a certain amount of the interpreter's (translator's) orientation towards reality: "any use of linguistic signs involves their interpretation with the respect to each other and in relation to reality" and "we cannot imagine the process of translation without any reference to reality in a sense that without taking into account the situation described it is neither possible to understand the original, nor to provide translation equivalence" (Komissarov, 1982: 6-7). Thus, the translator (interpreter) often resorts to the use of the procedure of interpretation. At the same time V.N. Komissarov points at the ambiguity of this term and distinguishes two types of interpretation as phases of translation (interpreting) (Komissarov, 1982: 11):

The scholar states that the first type of interpretation deals with setting up the translation process, and involves mainly finding correspondences (dictionaries, glossaries, tutorials and so on). It touches upon the appropriateness of the use of correspondences known to the translator, choosing between alternatives and etc.;

The second type of interpretation involves finding a new (or unknown by now to the 
interpreter) correspondence or contextual match (ad hoc) through self-translation, taking into account the context of the features described by the reality of the situation in the act of translation (interpreting), and other relevant factors.

It is very important to highlight that V.N. Komissarov believed that these types of interpretation cannot be separated from the translation process, because they harmoniously coexist with it and are its integral part.

In the $21^{\text {st }}$ century Russian scholars more frequently use the concept of entropy to talk about interpretation. The notion of entropy historically was used in thermodynamics. This concept was initially introduced by the German physicist

R. Clausius, and later it was developed by L. Boltzmann, J. W. Gibbs, and J. C. Maxwell scientists whose major contribution led to the establishment of the statistical models of entropy (Second Law of Thermodynamics and Entropy). The idea of entropy has become a popular approach to many scientific problems (e.g. Nature journall by now has published over five thousand articles which have the term "entropy" in their headings. It is certain that this journal can serve as a benchmark of productivity for scientific terms in natural sciences). We can trace direct analogies between the application of that concept in natural sciences, social sciences and humanities (e.g. translation studies): when entropy grows inside the message received by the interpreter through his (her) headset the understanding linkages between the concepts will weaken just like "replicated Escherichia coli daughter strands will spontaneously demix as a result of entropic forces, despite their strong confinement within the cell" - a biological type of entropy driven process (Jun, Wright, 2010). We are sure that one of the most fruitful ways to view the problem of understanding the message departs from the standpoint that it belongs to the domain of information theory (Shannon, 1963). One of the main points of this theory states that information transmitted by a certain communication channel always contains a certain amount of entropy, which is defined as "the value of the uncertainty of information" (Kolmogorov, 1987, 35). The higher the entropy value, the higher the percentage of information loss. Entropy as a measure of information uncertainty is a category defined by a number of factors affecting its magnitude. The factors can be divided into external (technical) and internal (personal). T.A. Kazakova, relying on the definition of information offered by Wiener, notes that "the content (meaning) of the text" in the information approach can be represented as "a structure to be reconstructed, in particular in the process of translation", meanwhile the concept of information in translation is defined as "a more or less distinct (informational) image of the original text in the perception of the interpreter (translator)" (Kazakova, 198-199). In addition to that it is necessary to point out that entropy as a phenomenon hinders the process of reconstruction, conducted by interpreters (translators). Initially it occurs at the stage of "decoding" the image of the source text, and we face "secondary" entropy at the stage of "coding" the image of text to be interpreted (translated). Another significant feature of entropy in connection with simultaneous interpreting is its anisotropy, i.e. since in simultaneous interpreting the interpreter quite often speaks one language more fluently than the other the information channel is anisotropic. One way to reduce entropy in the interpreting process (in particular simultaneous interpreting) is to use the mechanism of probabilistic forecasting. One of the most respected and recognized Russian researchers of simultaneous interpreting, G.V. Chernov indicates that the mechanism of probabilistic forecasting relies upon "the fundamental methodological concept of anticipatory reflection of reality, events of the outside world in the living protoplasm, 
which was put forward by the scholars of the Soviet school of physiology, and is defined as "the basic form of adjustment of living matter to the spacetime structure of the inorganic world, where consistency and reproducibility are key timing parameters" 2 (Chernov, 2009, 56). G.V. Chernov insists that "along with the process of auditory speech perception the interpreter's brain proposes hypotheses about variants of particular semantic or verbal development or completion of the speaker's intentions" (ibid.). In this case the term "redundancy", as was noted by G.V. Chernov, "appeared in the theory of information and was associated with the name of its creator $\mathrm{C}$. Shannon, now widely penetrated in linguistics, psychology and related disciplines" (ibid. ).

\section{Conclusion}

We do realize that this paper is just an initial step in the long process of comprehensive comparison between two academic traditions; each of them has its own cultural peculiarities, supporters and scientific opposition. The main objective of the paper was to illustrate the difference and similarity of Russian and Chinese schools of thought: both schools focus on interpretation as a separate procedure in the process of translation, however Chinese scholars pay more attention to the traditional hermeneutic approach, whereas Russian think-tanks seem to elaborate a better psychological understanding of this notion.

\section{References}

Chernov, G.V. Teoriya i praktika sinhronnogo perevoda [Theory and practice of simultaneous translating], Moscow, Publishing House "LIBROKOM", 2009, 208 p.

Demyankov V.Z. Interpretatsia kak metodoligia lingvisticheskih issledovanii [Interpretation as a methodology of linguistic research] // Man Language Arts: International scientific-practical conference on 14-16 November 2000, Moscow, 67-68pp.

Gauker Ch., Words without meaning, New-York, 2003, 340p.

Jun, S., Wright, A. Entropy as the driver of chromosome segregation (2010) Nature Reviews Microbiology 8, pp. 600-607 doi:10.1038/nrmicro2391

Kazakova, T.A. Perevod kak pererabotka informatsii [Translation as information processing], 11 Fodorovskiye chteniya. Universitetskoye perevodovedeniye [Fedorov Readings XI, University Translation Studies], Saint-Petersburg. pp. 197-201.

Kolmogorov, A.N. Teoriya informatsii i teoriya algoritmov [Information theory and theory of algorithms], Moscow, Nauka (Science), 1987. 304 p.

Komissarov V.N. Perevod kak ob ekt perevodcheskogo issledovania [Translation as an object for research in translation studies], Moscow, 282p.

Leontiev A.N. Deyatelnost, soznanie [Activity, Consciousness], Moscow, 1975, 185p.

Leontiev A.N. Problemi razvitia psikhiki [Propblems of development of psychology], Moscow, 1972, 192p.

Marcelo Dascal, Interpretation and Understanding John Benjamins Publishing Company 2003. xxii, 714 pp DOI: $\underline{10.1075 / \text { z.120 }}$

Mikeshina L.A. Philosophy of Science, Moscow, 2005, 464p.

Routledge Encyclopedia of Translation Studies, London and New-York, Routledge, 2001, 655p.

Second Law of Thermodynamics and Entropy (Lecture 24). Yale University Open Courses. Available at: http://oyc.yale.edu/physics/phys-200/lecture-24 (accessed 8 October 2016).

$$
-589-
$$


Shannon, C. Raboty po teorii informatsii $i$ kibernetike [Works on information theory and cybernetics], Moscow, Foreign Literature Publishing, 1963, 832 p.

Sokolovsky Y. V. On Entropy in Simultaneous Interpreting, Journal of Siberian Federal University. Humanities \& Social Sciences 2 (2014 7) 320-325 pp.

Wang Yan Hua, the hermeneutical perspective of the standard translation changes, Shanghai Polytechnic University Journal of Social Sciences Edition, vol. 34 No. 1, 20123 September, pp. 24-35

Zalevskaya A. Vvedenie v psikholingvistiky [Introduction to psycholinguistics], 1999, 182p.

Zhao Lijuan, the interpretation of Science translation research: review and prospect, Lanzhou Jiaotong University Journal, 2010, 5 October, pp. 130-133 pp.

\title{
К вопросу об интерпретации
}

\section{и понимании в переводе: \\ обзор взглядов российских}

и китайских исследователей

\author{
Шаоцзюнь Чэнь ${ }^{\mathrm{a}}$, Я.В. Соколовский ${ }^{\mathbf{\sigma}}$ \\ а Шанхайский университет международных \\ отномений \\ КНР, Шанхай, пр. Далянь, 50 \\ ${ }^{\sigma}$ Сибирский федеральный университет \\ Россия, 660041, Красноярск, пр. Свободный, 79
}

Несмотря на кажущуюся простоту понятия «интерпретация» до настоящего времени не существует общепринятой точки зрения на данное понятие в лингвистике в целом.

В данной статье кратко рассматривается данное понятие и степень его представленности в гносеологических конџепциях китайских и российских переводоведов и лингвистов. Авторы делают попытку краткого обзора некоторых существующих конщепџий в рамках данной проблематики с учётом переводческой спеиифики.

Ключевые слова: интерпретация, перевод, проблема понимания, проблема смысла, китайский.

Научная спещиальность: 10.00.00 - филологические науки. 